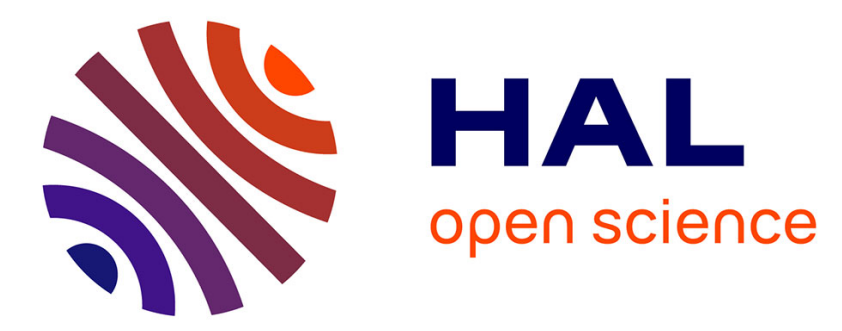

\title{
The first Malcidae (Hemiptera, Heteroptera) from the earliest Eocene Oise amber
}

Marie Camier, Antoine Logghe, André Nel, Romain Garrouste

\section{To cite this version:}

Marie Camier, Antoine Logghe, André Nel, Romain Garrouste. The first Malcidae (Hemiptera, Heteroptera) from the earliest Eocene Oise amber. Historical Biology, 2019, pp.1-5. 10.1080/08912963.2019.1675058 . hal-02337318

\section{HAL Id: hal-02337318 \\ https://hal.sorbonne-universite.fr/hal-02337318}

Submitted on 29 Oct 2019

HAL is a multi-disciplinary open access archive for the deposit and dissemination of scientific research documents, whether they are published or not. The documents may come from teaching and research institutions in France or abroad, or from public or private research centers.
L'archive ouverte pluridisciplinaire HAL, est destinée au dépôt et à la diffusion de documents scientifiques de niveau recherche, publiés ou non, émanant des établissements d'enseignement et de recherche français ou étrangers, des laboratoires publics ou privés. 


\section{The first Malcidae (Hemiptera, Heteroptera) from the earliest Eocene Oise amber}

Marie Camier ${ }^{1}$, Antoine Logghe ${ }^{2}$, Andre $\mathrm{Nel}^{2}$ and Romain Garrouste ${ }^{2}$

17 rue de la Fontaine, F-59259 Lécluse, France. E-mail: mariecamier@icloud.com

${ }^{2}$ Institut Systématique Evolution Biodiversité (ISYEB), Muséum national d'Histoire naturelle, CNRS, Sorbonne Université, Université des Antilles, EPHE, 57 rue Cuvier, CP 50, F-75005 Paris, France. E-mail: anel@mnhn.fr

\section{ABSTRACT}

The earliest Eocene Eochauliops longicornis gen. et sp. n., first fossil Malcidae, is described from the amber of Oise (France). Together with the previous discovery of a species of Blissidae in the same amber, it suggests that the Lygaeoidea were already rather diverse during the Paleocene, even if the Mesozoic record of this superfamily remains uncertain and scarce.

\section{KEYWORDS}

Insecta; Heteroptera; Lygaeoidea; gen. et sp. nov.; Paleogene; dating

\section{Introduction}

The family Malcidae Stål, 1866 is a small lygaeoid clade that comprises only three extant genera (Henry et al. 2015), currently with no fossil record. More generally, the Lygaeoidea are rather infrequent in the fossil record (Garrouste, 2015). There is some uncertainty on the positions of the Mesozoic compression fossils currently attributed to this superfamily (Garrouste et al. 2019). Thus the discovery of the first fossil malcid from the earliest Eocene amber of France is of great interest. 


\section{Material and methods}

The fossil is embedded in a small clear piece of amber. It was prepared using a diamond disk, examined using a Nikon binocular microscope SMZ 1500. Photographs were taken with an Amscope camera MU900, and the images treated with Adobe Photoshop Element 12. The amber sedimentary layer is from the lower Eocene of the Paris basin (ca 53 million-years-old), during a global warming period, in a semi-deciduous forest with a mosaic of gallery-forest mixed with dryer plant communities, in a 'paratropical' region. The climate was hot, with both dry and wet seasons (Nel and Brasero, 2010).

The classification follows Henry (1997) and Štys (1967), and the morphological nomenclature given by Gao and Bu (2009). Dimensions are in millimeters.

\section{Systematic Paleontology}

Order Heteroptera Latreille, 1810

Superfamily Lygaeoidea Schilling, 1829

Family Malcidae Stål, 1866

Subfamily Chauliopinae Breddin, 1907

Genus Eochauliops gen. n.

Article urn:lsid:zoobank.org:pub xxxx

Type species. Eochauliops longicornis sp. n.

\section{Diagnosis}

Antennae long, extending to distal part of abdomen; first antennal segment greatly surpassing apex of clypeus for more than its half; ocelli widely separated; pronotum widest at base; lateral pronotal margin weakly carinate with a row of curved setae; at least two deep punctures on 
distal part of clavus; membrane with four indistinct parallel veins; hind femora unarmed; tergites not fused into a plate; sterna III to VI not fused; connexiva on abdominal segments VVII produced into conspicuous dentate lobes.

Etymology. Named after the Eocene period and the extant genus Chauliops. Gender neutral.

Eochauliops longicornis sp. n. (Figs 1-7)

Article LSID urn:Isid:zoobank.org:pub:40A50ED4-E964-4373-A051-C8C3BE176FCF

Genus LSID urn:Isid:zoobank.org:pub:40A50ED4-E964-4373-A051-C8C3BE176FCF

Species LSID urn:Isid:zoobank.org:pub:40A50ED4-E964-4373-A051-C8C3BE176FCF

Material. Holotype MNHN.F.A71302 (male, PA 2495), stored in the Paleontological Department, MNHN, Paris.

Diagnosis. As for the genus.

Etymology. Named after the long antennae, the main character of the genus.

Description. Male. Total body length $3.35 \mathrm{~mm}$. Head length $0.47 \mathrm{~mm}$, wider than long; width across eyes $0.75 \mathrm{~mm}$, lower than width at posterior margin of pronotum; interocular distance $0.36 \mathrm{~mm}$; preocular distance $0.57 \mathrm{~mm}$; declivent, triangular; antennal segment I robust, 0.42 mm long, barely curved, greatly exceeding apex of tylus (clypeus), segments II and III slender, cylindrical, subequal lengths, twice as long as I, respectively 0.87 and $0.85 \mathrm{~mm}$, segment IV narrowly fusiform, $0.55 \mathrm{~mm}$ long; antenniferous tubercle clearly visible from below and partly visible from above, unarmed; vertex low; eyes hemispheric, stylate and protuberant, at same level as vertex in lateral view; ocelli laterally encircled by a groove, visible from side of head, well separated, $0.25 \mathrm{~mm}$ apart; bucculae elongate, reaching posterior third of ventral part of head; rostrum extending to middle mesosternum; pronotum longer than wide, $0.85 \mathrm{~mm}$ long; width across humeral angles $0.94 \mathrm{~mm}$, slightly wider than head across eyes; subquadrate; pronotum almost rectangular; anterior and posterior borders straight; anterolateral borders with 
a series of curved setae, not emarginate, convex on middle third; transverse pronotal impression weak; collar-like region narrow; scutellum triangular, wider than long, ca $0.28 \mathrm{~mm}$ long and 0.49 mm wide, apex hidden by impurities; mesocoxae and metacoxae widely separated; fore femora unarmed, but with a series of setae; middle and hind femora unarmed; tibiae cylindrical, with a tibial comb on fore tibia; tarsi three-segmented, with first and third tarsomeres subequal; inner side of claws with transverse rugosities; distipulvillus broad with a lamellar surface; basipulvillus with numerous toothlike and sharp outgrowths; one pair of bristle-like parempodia present, base of each parempodium with a stout spine; ventral terminal margin of 3rd tarsomere with one long microtrichia; hemelytron $2.23 \mathrm{~mm}$ long; as wide as pronotum; clavus and corium separated by a furrow, convex; costal margin broadly emarginated; at least two deep punctures on distal part of clavus and numerous on corium; membrane well-developed with four parallel indistinct veins; abdominal spiracles on dorsal external laterotergites; tergites not fused into a plate; sterna III to VI not fused; connexiva on abdominal segments V-VII produced into conspicuous dentate lobes; sternites III and IV without visible trichobothria; sternites V and VI with three lateral trichobothria; sternum VII with one large and one smaller posteromedial trichobothrium.

\section{Discussion}

The general habitus of this fossil clearly resembles extant members of the family Malcidae. Henry (1997) proposed the 'presence of three trichobothria on some sternites' as a synapomorphy of the clade (Coreoidea + Idiostoloidea + Lygaeoidea + Pyrrhocoroidea), and the character state 'reduced or simple hemelytral venation with only 3-4 simple veins and lacking closed cells at the base of the membrane' as a synapomorphy for the Lygaeoidea, Both are present in Eochauliops, supporting its attribution to the Lygaeoidea. 
Following Henry's (1997) key to the families of Lygaeoidea, Eochauliops goes to the Malcidae because of the following characters: abdominal spiracles dorsal; tarsi threesegmented; ocelli present; each ocellus laterally encircled by a groove; connexiva on abdominal segments V-VII produced into conspicuous dentate lobes; lateral pronotal margin weakly carinate. Henry (1997) characterized the Malcidae by the following synapomorphies: a stout, elongate 1st antennal segment; connexival processes on the laterotergites; and stylate eyes.

Štys (1967) and Henry (1997) considered the Malcidae monophyletic after morphological analyses, but Li et al. (2017) did not recovered the Malcidae as monophyletic in their molecular analysis but in a mixed set with Geocoris and Kleidocerys. The Malcidae currently comprise the three genera Malcus Stål, 1859 (Malcinae), Chauliops Stål, 1859, and Neochauliops Štys, 1963 (Chauliopinae). After Štys (1967), Eochauliops gen. n. falls into the Chauliopinae rather than in the Malcinae because of the following characters: ocelli distant from each other, not situated on a common tubercle; stylate eyes; large antenniferous tubercles; first and third tarsomeres subequal; veins on membrane unsclerotized, hardly visible; abdominal mediotergites not fused in a common plate. Also, the dentate lobes of the connexiva of abdominal segments V-VII are similar in size and ornamentation to those of Chauliops horizontalis Zheng, 1981 (Gao and Bu, 2009). However, the antenniferous tubercles are not clearly spinously produced unlike in the extant Chauliopinae. Also the antennae are long, reaching the level of the apical third of abdomen as in the extant Malcus (Kondorosy, 2000), whereas in the Chauliopinae, they are clearly shorter (Štys, 1967). Eochauliops gen. n. shares with Chauliops and Malcus the presence of at least two deep punctures on the distal part of the clavus, whereas these structures are absent in Neochauliops (Štys, 1963). The unarmed hind femora is also a characters present in Eochauliops gen. n., Malcus and Chauliops bisontula Banks, 1909 (Štys, 1963). 


\section{Conclusion}

Eochauliops gen. n. is the first fossil malcid. The Lygaeoidea are supposed to be rather ancient, with several Jurassic and Cretaceous compression fossils currently attributed to this clade, but Garrouste et al. (2019) questioned their attributions. Li et al. (2012), after a molecular phylogenetic analysis, dated the Cymidae: Lygaeoidea from the Eocene (ca. 45 Ma.), and more recently Li et al. (2017) dated both Malcinae and Chauliopinae from the Early Cretaceous (ca. $130 \mathrm{Ma}$ ), which is more congruent with the putative presence of Lygaeoidea in the Cretaceous. There are unstudied Lygaeoidea known from the Lower Cretaceous Lebanese amber (Dany Azar pers. comm.). The current discovery of a species of Malcidae, together with the previous discovery of a Blissidae in the Lowermost Eocene Oise amber (ca. 53 Ma.), suggests that the Lygaeoidea were already rather diverse during the Paleocene.

Extant Malcidae are distributed in the Afrotropical and Oriental regions. Štys $(1963,1967)$ suggested that Burma and the surrounding mountains could be considered a center of speciation for Malcinae and Chauliopinae. The presence of this family in the European Eocene shows that this family was much more widespread during the Paleogene and that their history is certainly more complex than previously documented. The discovery of this taxon also supports the tropical to sub-tropical climate presence in the Oise amber paleoforest (Nel and Brasero, 2010). The recent discovery of Malcus elongatus Štys as an invasive in Crete (Roca-Cusach and Goula, 2017) shows that these bugs can adapt to a Mediterranean climate.

\section{Acknowledgements}

We greatly thank T.J. Henry for his help in the establishing family position of the fossil. Also we thank two anonymous referees for their useful comments on the first version of this paper. We also thank Gael De Ploëg for his crucial help in the collect and study of the fossil insects of 
Oise amber. We thank the Lafarge-Granulat company for help with the fossil sampling and the Langlois-Meurinne family for the authorization of working on their property.

\section{Disclosure statement}

No potential conflict of interest was reported by the authors.

\section{References}

Banks, C.S. 1909. Rhynchota Palawanica, Part I; Heteroptera. Philippine Journal of Sciences (A). 4:553-591.

Gao, Cui-qing and Bu, Wen-jun 2009. Notes on fine structures of Chauliops with descriptions of two new species from China (Insecta: Hemiptera: Heteroptera: Malcidae). Zootaxa. 2295:114.

Garrouste, R., Nel, A. 2019. The first chinch bug Blissidae (Hemiptera, Heteroptera) from the Eocene Oise amber. Palaeoentomology. 2:85-93.

http://dx.doi.org/10.11646/palaeoentomology.2.1.6

Henry, T.J. 1997. Phylogenetic analysis of family groups within the infraorder Pentatomorpha (Hemiptera: Heteroptera), with emphasis on the Lygaeoidea. Annals of the Entomological Society of America. 90:275-301.

Kondorosy, E. 2000. Three new species of Malcus Stål, 1859 (Heteroptera, Malcidae) from Vietnam. Acta Zoologica Academiae Scientiarum Hungaricae. 46:231-238.

Li, H., Leavengood J.M. Jr., Chapman, E.G., Burkhardt, D., Song, F., Jiang, P., Liu, J.P, Zhou, X.G., Cai, W.Z. 2017. Mitochondrial phylogenomics of Hemiptera reveals adaptive innovations driving the diversification of true bugs. Proceedings of the Royal Society (B). 284 (20171223):1-10. https://doi.org/10.1098/rspb.2017.1223

Li, M., Tian, Y., Zhao, Y., Bu, W.J. 2012. Higher level phylogeny and the first divergence time 
estimation of Heteroptera (Insecta: Hemiptera) based on multiple genes. PLoS One. 7 (2) (pe32152):1-17. https://doi.org/10.1371/journal.pone.0032152

Nel, A., Brasero, N. 2010. Oise amber. Pp. 137-148. In: Penney, D. (ed.). Biodiversity of fossils in amber from the major world deposits. Siri Scientific Press, Manchester.

Roca-Cusachs, M., Goula, M. 2017. First record of the family Malcidae (Heteroptera: Lygaeoidea: Malcidae) in Western Palaearctic: invasive species or casual record? Arquivos Entomolóxicos. 17:289-292.

Stål, C. 1859. Hemiptera species novas descriptsit. Konglika Svenska Fregattens Eugenies resa omkring jorden under Befäl af C. A. Virgin åren 1851-1853, 3 (Zoologi, Insekter):219-298. Štys, P. 1963. Notes on the taxonomy, distribution and evolution of the Chauliopinae (Heteroptera: Lygaeidae). Acta Universitatis Carolinae, (Biologica). 1963:209-215. Štys, P. 1967. Monograph of Malcinae, with reconsideration of morphology and phylogeny of related groups (Heteroptera: Malcidae). Acta Entomologica Musei Nationalis Pragae. 37:351516.

Zheng, Le-Ti 1981. A new Chauliops (Heteroptera: Lygaeidae) from China. Acta Entomologica Sinica 24:188-189.

Figure 1. Eochauliops longicornis gen. et sp. n., holotype MNHN.F.A71302. Habitus. (A) dorsal; (B) ventral. Scale bars $=1 \mathrm{~mm}$.

Figure 2. Eochauliops longicornis gen. et sp. n., holotype MNHN.F.A71302. (A) antennae; (B) lateral margin of pronotum; (C) fore leg, arrows setae of femur. Scale bars $=0.5 \mathrm{~mm}(\mathrm{~A}, \mathrm{C}) ; 0.2$ $\mathrm{mm}(\mathrm{B})$

Figure 3. Eochauliops longicornis gen. et sp. n., holotype MNHN.F.A71302. Forewing. Scale bar $=1 \mathrm{~mm}$. 
Figure 4. Eochauliops longicornis gen. et sp. n., holotype MNHN.F.A71302. Apex of abdomen, ventral, arrow dentate lobes of connexiva of abdominal segment VII. Scale bar $=0.2$ $\mathrm{mm}$.

Figure 5. Eochauliops longicornis gen. et sp. n., holotype MNHN.F.A71302. Head, black arrows ocelli, white arrow groove. Scale bar $=0.5 \mathrm{~mm}$.

Figure 6. Eochauliops longicornis gen. et sp. n., holotype MNHN.F.A71302. Distal part of clavus, black arrows deep punctures. Scale bar $=0.2 \mathrm{~mm}$.

Figure 7. Eochauliops longicornis gen. et sp. n., holotype MNHN.F.A71302. Claws. Scale bar $=0.1 \mathrm{~mm}$. 


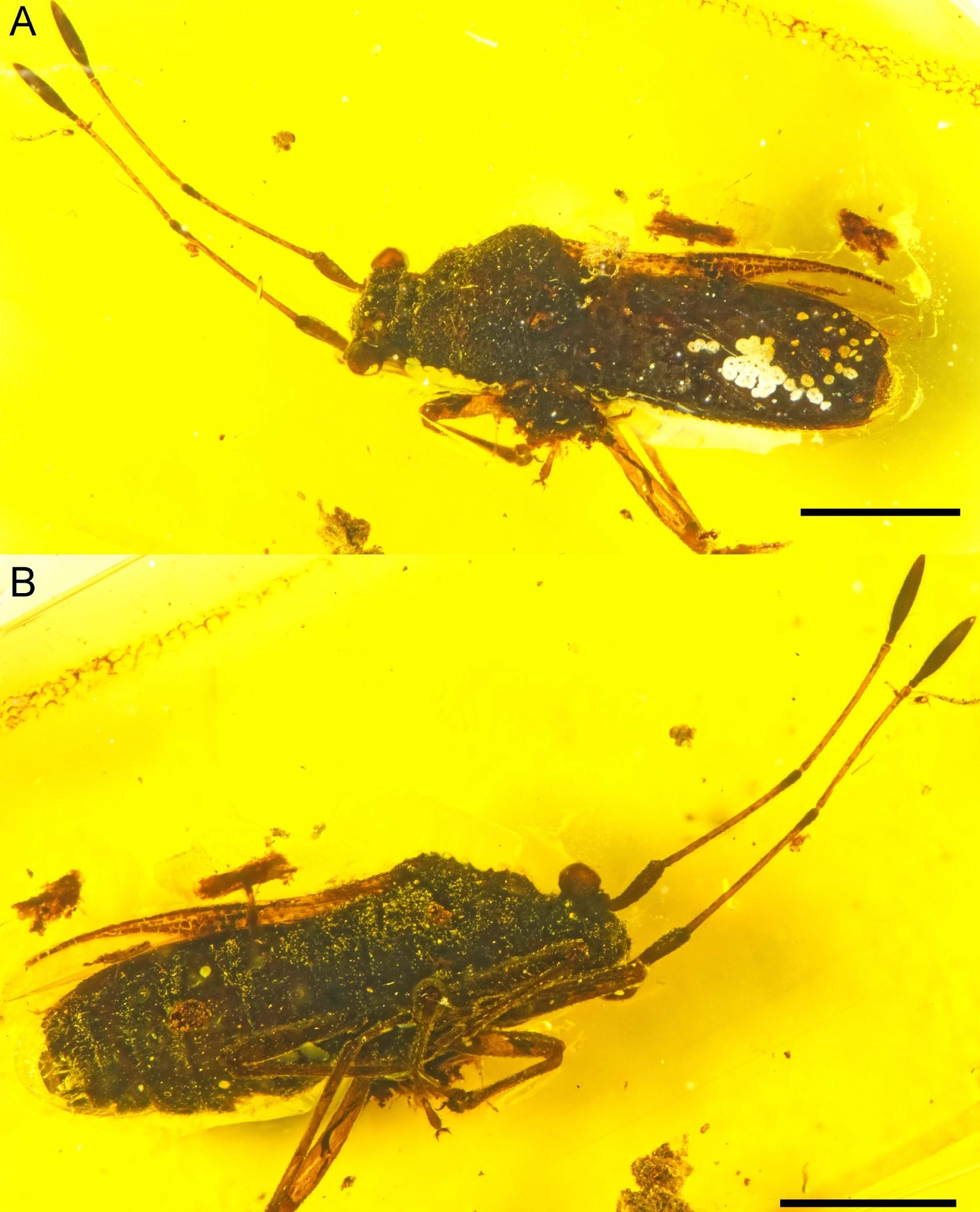




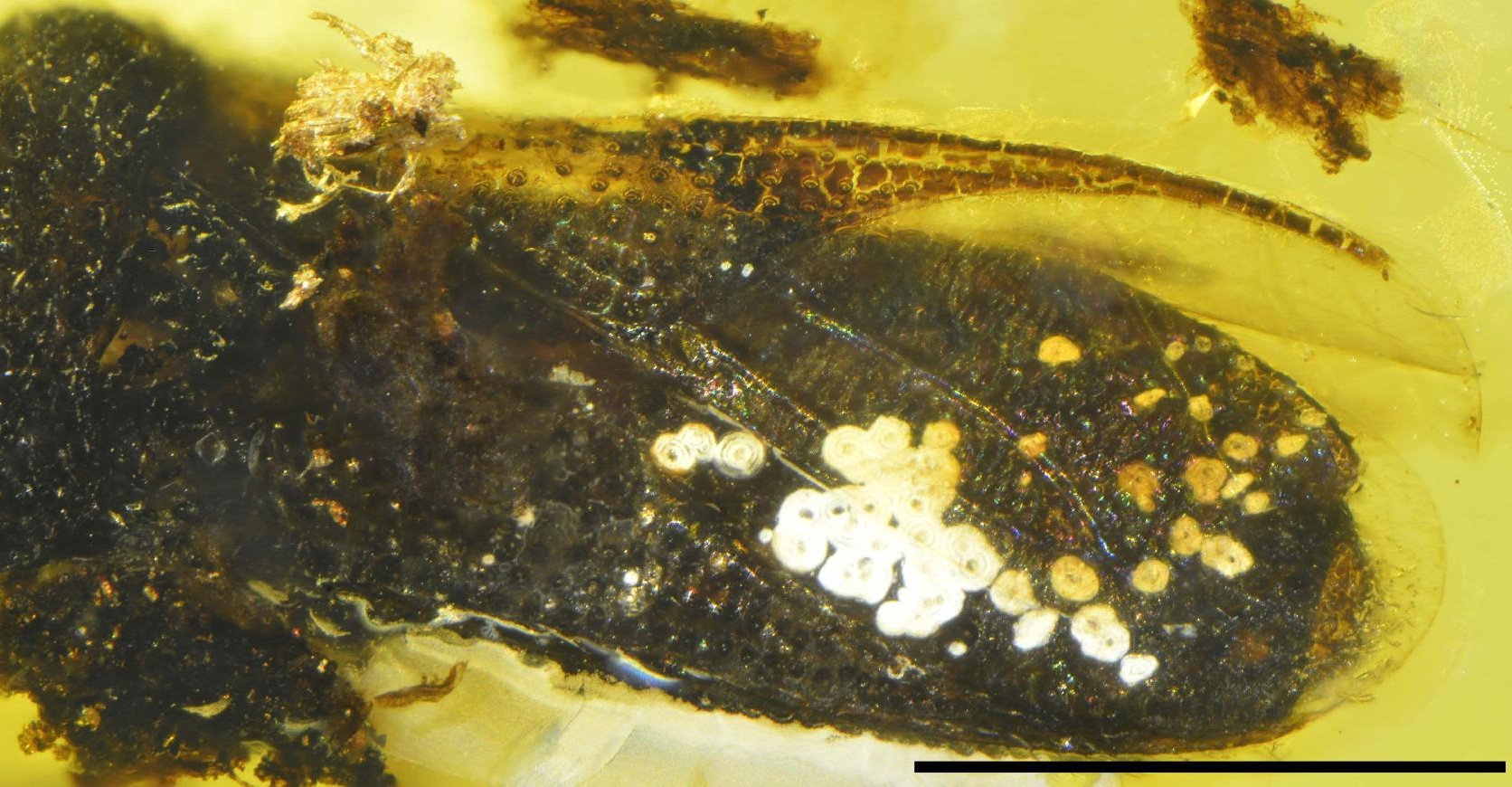




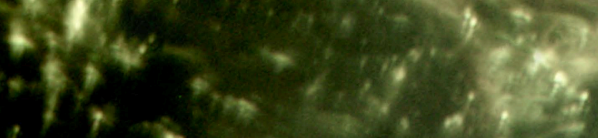

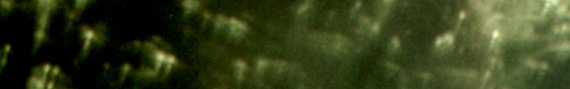

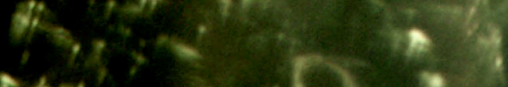

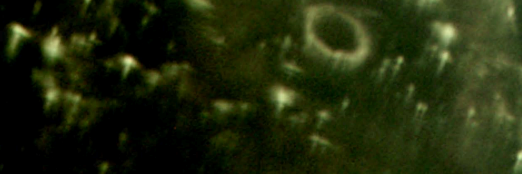

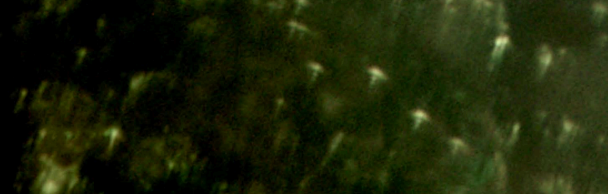

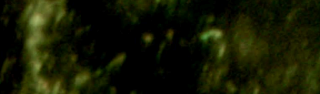

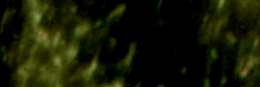
Q
4.9
$y^{3} x^{2}$

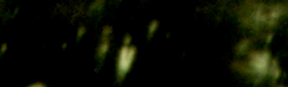

(2)

f. $N, 1$,

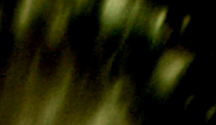

1.8 18

ans

$\operatorname{lin}^{2} x=$

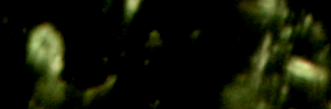

4.45

Asts

4.

7

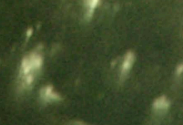

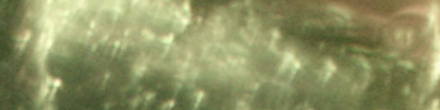

$(4,5)$

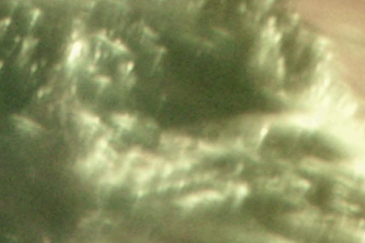

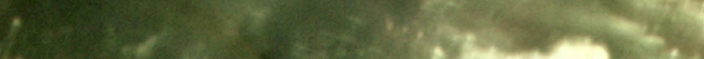

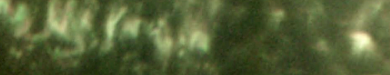

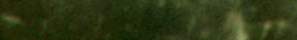

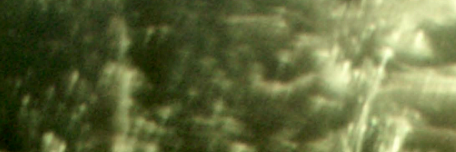

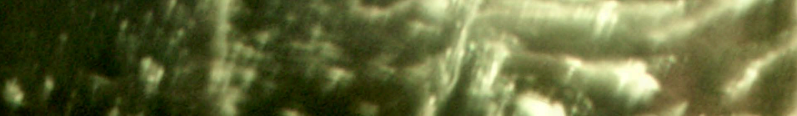

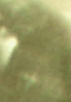
$\operatorname{lin}^{2}$.

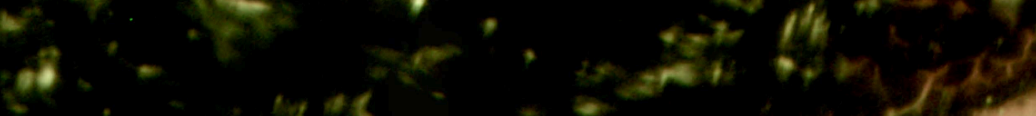

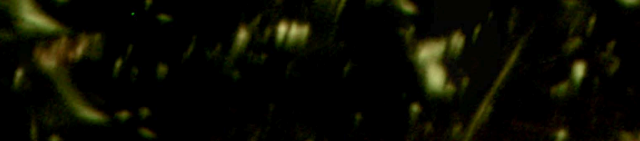
$\sqrt{1} \times$ i. 


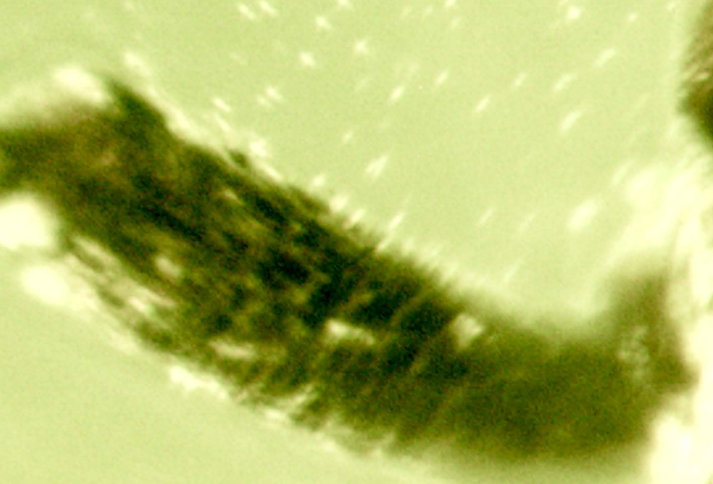

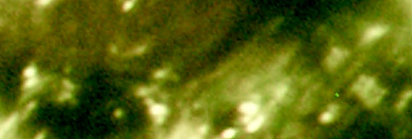

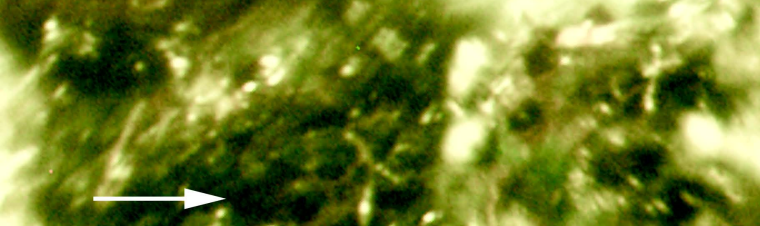

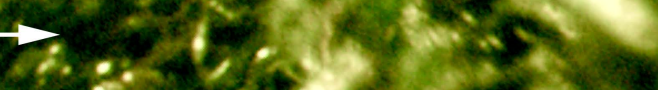

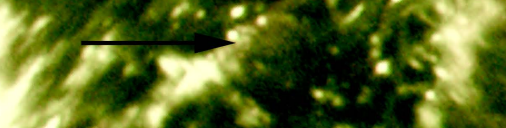

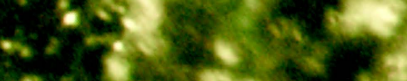

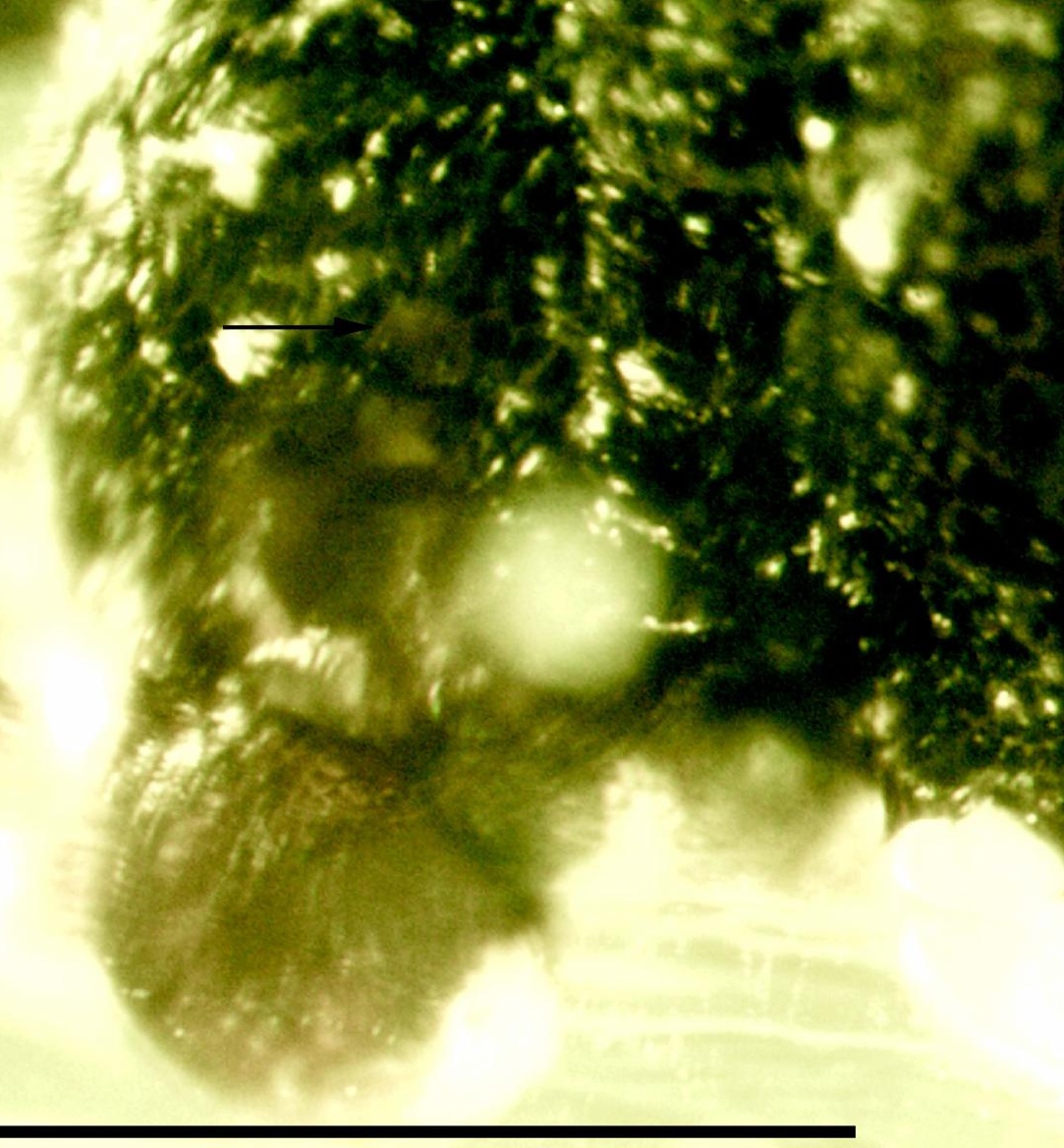




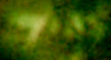
(4)

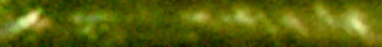

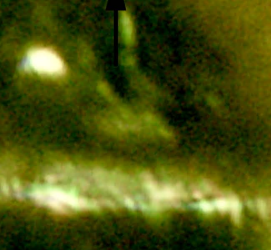
witions

e

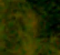
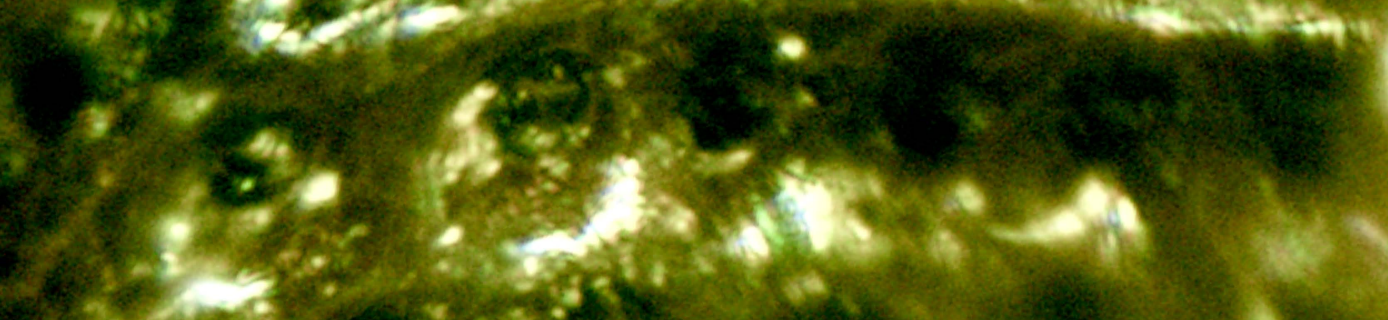
(5)

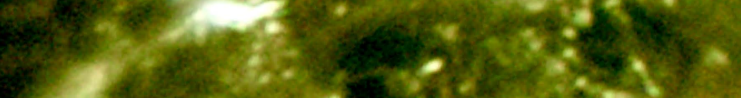

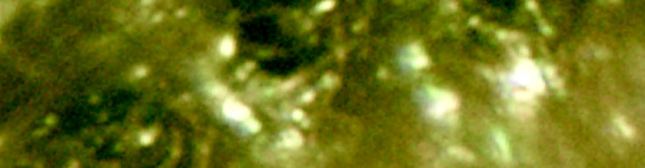
e.

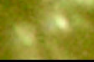
45:

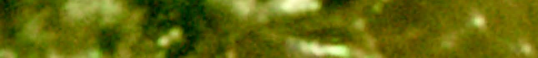


